\title{
Polyaromatic Hydrocarbons in Dust Particles of Moravian-Silesian Region (Czech Republic) in the Winter Season 2013/2014
}

\author{
Marek Kucbel, Barbora Sykorova, Helena Raclavska, Konstantin Raclavsky, Dalibor Matysek \\ VSB - Technical university of Ostrava, Ostrava, Czech Republic
}

\begin{abstract}
Analytes corresponding to 16 polyaromatic hydrocarbons were determined from dust aerosol particles collected on filters at $\mathbf{4 0}$ localities of the industrial MoravianSilesian Region (Czech Republic). Comparison is performed for areas of different character (mountains, towns with and without industry).
\end{abstract}

Keywords- polyaromatic hydrocarbons; dust aerosol particles; cluster analysis; Moravian-Silesian Region.

\section{INTRODUCTION}

Polyaromatic hydrocarbons (PAHs) belong to the semivolatile organic compounds formed during partial combustion of organic materials, coal, oil, earth gas or wastes $[1,2]$. PAHs can enter into atmosphere in two forms: bound to the dust particles as p-PAHs (particulate - PAHs) or in gaseous form as g-PAHs (gas-PAHs) [3]. Percentages of PAHs in gaseous and solid phase depend on vapour pressure of PAHs, temperature, specific surface of particles and affinity of PAHs to the organic particles $[1,4]$. From the point of view of distribution of PAHs between both phases, characteristics of particles are important (particle size, chemical composition of particles, the content of black carbon, relative humidity of ambient atmosphere [7].

According to US EPA, 16 priority PAHs include those with 2 rings: Nap, 3 rings: Acp, Ac, Py, Ant, Phe and Flu, 4 rings: $\mathrm{B}[\mathrm{a}] \mathrm{P}, \mathrm{B}[\mathrm{b}] \mathrm{F}, \mathrm{B}[\mathrm{k}] \mathrm{F}$ and $\mathrm{D}[\mathrm{a}, \mathrm{h}] \mathrm{A}, 6$ rings: $\mathrm{B}[$ ghi $] \mathrm{P}$ and Ind. COR formed by 6 rings is considered to be indicator of emissions from transport. Combustion at low temperatures (e.g. combustion of wood) produces PAHs with low molecular weight while high temperature processes release PAHs with higher molecular weight $[8,9]$. Most of PAHs originated by combustion of biomass have low molecular weight, they are unstable and form more than $86 \%$ of total PAHs found in the gaseous phase $[8,10]$. Among PAHs emitted during production of steel and iron (when coal is used as a fuel) rank $\mathrm{B}[\mathrm{a}] \mathrm{A}, \mathrm{B}[\mathrm{k}] \mathrm{F}, \mathrm{B}[$ ghi] $\mathrm{P}$ and in the case of electric arc furnace COR, Pyr and $B[b] F$ have highest concentration [11].

Emissions from petrol engines are formed prevalently by PAHs with 4 and 5 rings. The most important PAHs from exhaust gases of petrol engines are $\mathrm{COR}$, Ind and $\mathrm{B}$ [ghi]P $[12,13,14]$. Emissions from Diesel engines are characterized by PAHs with 3 rings $[4,8,11]$, mostly Fl and Pyr $[12,13]$. In urban areas the largest part in $\Sigma$ PAHs consists of emissions from transport [10,15]. Emissions form domestic combustion are mostly related to the combustion of coal, wastes, gas biomass or other organic matter. An origin of PAHs in emissions if influenced prevalently by origin and kind of fuel as well as by many technological factors (amount of oxygen, combustion temperature, fuel moisture) [8].Acp, Fl and Nap were identified as typical representatives of PAHs from small industrial boilers [16]. The similar results were reported for 25 industrial boilers where in emissions of PAHs prevailed Nap [17].

PAHs represent serious problem in atmosphere of the Czech Republic. The total limit of deposition for benzo[a]pyrene is exceeded at $70 \%$ of measuring stations in the Czech Republic. The most important exceedance was measured in the city of Ostrava where the annual mean value for 2013 was $9.2 \mathrm{ng} / \mathrm{m}^{3}$ and in the town of Karvina where it was $3.1 \mathrm{ng} / \mathrm{m}^{3}$. During the winter season 2013/2014, the deposition limit for B[a]P was only met at 2 from 40 monitored localities.

The aim of this study is verification of possibility to identify the pollution sources by means of utilization of individual PAHs, division of localities into areas based on the environmental knowledge and application of cluster analysis.

\section{SAMPLING SITES AND THE METHOD OF ANALYSIS}

Measurements were performed during the winter season 2013/2014 at 40 localities of Moravian-Silesian Region (Fig.1), the northeastern part of the Czech Republic. The dominant industrial activities in Moravian-Silesian Region are metallurgy, exploitation of bituminous coal, the energy industry and chemical industry. The localities were divided into 4 categories according to the geographical position or prevailing activity:

- Mountain region with settlements: Nos. 10, 23, 30, 31 and 35

- Region with prevalence of domestic heating: Nos. $7,8,9,11,12,13,14,15,19,26,27,28,29,33,36,38$ and 39

- Industrial conurbation: Nos. 1, 2, 3, 4, 5, 6, 17, 20 and 21

- Towns without significant industrial activity: Nos. $16,18,22,24,25,32,34,37$ and 40 . 


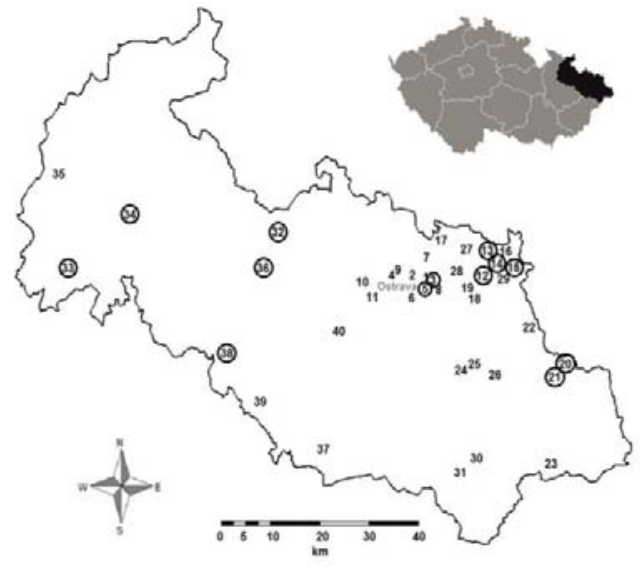

Figure 1. Sampling sites of PAHs. $\mathrm{O}$ - Exceedance of geochemical background

1. Ostrava-Radvanice, 2. Ostrava-MarianskeHory, 3. Ostrava-Radvanice OZO, 4. Ostrava-Poruba, 5.Ostrava-Radvanice church, 6.Ostrava-Dubina, 7.Ostrava-Hermanice, 8.Senov, 9.Ostrava-Hostalkovice, 10. KlimkoviceSanatoria,11 Klimkovice, 12. Karvina Doly, 13. Karvina Stare Mesto, 14. Karvina Frystat, 15. Karvina-Raj,16. Karvina, 17. Bohumín-Skrecon, 18. Havirov, 19. Havirov-Sumbark, 20. Trinec, 21.Trinec-Oldrichovice, 22.CeskýTesin, 23. HorniLomna, 24. Frydek-Mistek A, 25.Frydek-Mistek B, 26. Nosovice, 27.Orlova, 28.Petrvald, 29.Stonava, 30.Ostravice, 31.Celadna, 32.Opava, 33.Rymarov, 34.Bruntál, 35.KarlovaStudanka, 36. Hradec nadMoravici, 37. NovyJicin, 38. Vitkov, 39. Odry, 40.Bilovec.

Dust aerosol was sampled at the locality during period of 24 hours by means of high-volume sampler Digittel MD 05 using glass-microfibre filters for catching of dust aerosol particles and PAHs sobbed on them. Polycyclic aromatic hydrocarbons was determined by method HPLC-PDA according to ISO 11338-2 "Stationary source emissions -
Determination of gas and particle phase - polycyclic aromatic hydrocarbons - Part 2. Sample preparation, clean up and determination. ISO Geneve 2003" and method isotopic dilution using HRGC-HRMS in the laboratories ALS Czech.

\section{GEOCHEMICAL BACKGROUND OF PAHs}

The value of geochemical background in the period of winter season 2013/2014 in Moravian-Silesian Region was for $\Sigma 16$ PAHs $450 \pm 180 \mathrm{ng} / \mathrm{m}^{3}$. Geochemical background was determined by the method of the calculated distribution function $[18,19]$. The values of geochemical background for the separate determined PAHs are listed in Table 1. The determined values of geochemical background for separate analytes and $\Sigma 16$ PAHs were compared with arithmetical mean of different categories. The values of geochemical background for separate analytes of PAHs were not exceeded only for localities in mountain areas. In areas with prevailing industrial activities, the values of geochemical background were exceeded for all studied analytes with exception of Nap. In areas with typical load from domestic heating, the values of geochemical background were exceeded for Nap, AcPy, Acp, Flu, B[a]A and also IND. In urban environment without direct influence of industry, the value of geochemical background was exceeded only for IND. In areas influenced by transport, concentrations of analytes Ant, B[a]A, CHR, IND were higher than geochemical background. The lowest number of exceedance events for all studied analytes was found for locality No.10 Klimkovice-Sanatoria (spa). This site can be regarded as a background locality. The exceedance of the value of geochemical background for $\Sigma 16$ PAHs is marked by circle around the number for the respective localities in Fig.1.

TABLE I. GEOCHEMICAL BACKGROUND FOR ANALYTES OF PAHS [NG/ $\left.{ }^{3}\right]$

\begin{tabular}{|l|l|l|l|l|l|}
\hline Analyte & $\begin{array}{l}\text { Geochemical } \\
\text { background }\end{array}$ & Analyte & $\begin{array}{l}\text { Geochemical } \\
\text { background }\end{array}$ & Analyte & $\begin{array}{l}\text { Geochemical } \\
\text { background }\end{array}$ \\
\hline Nap & $8.17 \pm 1.92$ & B [a]P & $17.14 \pm 6.58$ & FL & $71.32 \pm 26.75$ \\
\hline AcPy & $21.65 \pm 7.61$ & IND & $3.77 \pm 4.56$ & Pyr & $47.49 \pm 18.71$ \\
\hline Acp & $1.99 \pm 0.63$ & Di[a,h]A & $2.27 \pm 0.77$ & B $[\mathrm{b}] \mathrm{F}$ & $13.63 \pm 4.96$ \\
\hline Flu & $54.03 \pm 18.79$ & B[g,h,i]P & $12.14 \pm 3.76$ & B $[\mathrm{k}] \mathrm{F}$ & $8.20 \pm 3.15$ \\
\hline Phe & $130.66 \pm 48.84$ & B[a]A & $19.03 \pm 7.74$ & CHR & $19.94 \pm 7.48$ \\
\hline Ant & $14.93 \pm 4.92$ & & & & \\
\hline
\end{tabular}

Explanations: Nap - naphthalene, AcPy - acenaphtylene, Acp - acenaphtene, Flu - fluoranthene, Phe - phenanthrene, Ant - anthracene, B[a]P Benzo[a]pyrene, IND - Indeno[1,2,3-cd]pyrene, Di[a,h]A - dibenzo[a,h]anthracene, B[g,h,i]P - benzo[g,h,i]perylene, B[a]A - benzo[a]anthracene, Fl fluorene, Pyr - pyrene, B[b]F - benzo[b]fluoranthene, B[k]F - benzo[k]fluoranthene, CHR - chrysene.

Identification of localities with the highest load of PAHs was performed using threshold of geochemical anomaly (mean concentration $+2 \mathrm{x}$ standard deviation). Threshold of geochemical anomaly was exceeded for following localities: 3 Ostrava-Radvanice (11 analytes), 12 Karvina Doly (10), 14 Karvina Frystat (12), 15 Karvina Raj (12), 21 Oldrichovice (3), 28 Petrvald (1), 32 Opava (9), 33 Rymarov (1), 31 Bruntal (1) and 36 Hradec nadMoravici. The highest load of PAHs in atmosphere of MoravianSilesian Region was found in the close vicinity of metallurgical complex of Arcelor Mittal Company. Similarly, the town quarter Ostrava - MarianskeHory is much more influenced by increased concentrations in comparison with remaining parts of Ostrava (Dubina, Poruba, Hostalkovice). At the locality 36 Hradec nadMoravici, the domestic heating can be regarded to be the main source of PAHS. The locality 32 Opava is influenced by transport and domestic heating. 


\section{PERCENTAGES OF ANALYTES IN $\Sigma$ PAHS}

Different PAHs were divided into five groups on the basis of number of benzene rings (PAHs having lower molecular weight with 2 or 3 rings, middle molecular weight represented by 4 rings and PAHs with high molecular weight containing 5 or 6 rings). Percentages of PAHs belonging to these group at the individual localities are illustrated in Fig.2.Polyaromatic hydrocarbons with the same number of rings have similar physical and chemical properties as well as genesis and behaviour in the environment.

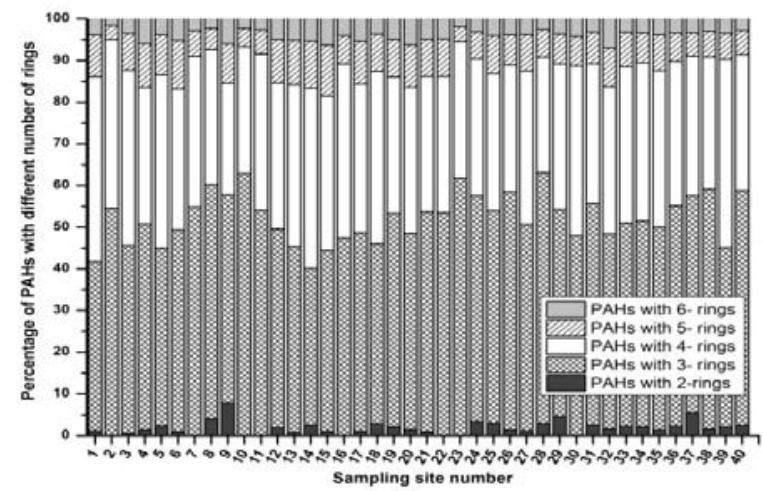

Figure 2. Percentages of PAHs with same number of rings in the sum of PAHs

The most abundant PAHs at the territory of MoravianSilesian Region are PAHs with 3 rings that occur in the range of values $37.7-62.9 \%$ The highest value of their percentage representation was found at the locality No. 10 Klimkovice - Sanatoria. The next group of significant representation is formed by PAHs with 4 rings that occur in the range $26.7-45.2 \%$. The highest value of their percentage representation was measured at the locality No. 39 Odry. Percentage representation of PAHs with 3 and 4 rings at the studied localities of Moravian-Silesian Region ranges between $76.7-95 \%$, these groups are thus dominant groups in the studied samples. The highest representation of PAHs wit 3 and 4 rings was observed at the locality No.2 Ostrava - MarianskeHory. Analytes of PAHs with 5 rings occur in the range $3.4-12.2 \%$. Analytes of PAHs with 6 rings have the lowest representation $1.6-7 \%$.

Comparison of median values for localities from defined areas does not provide significant differences in the distribution of PAHs according to the number of benzene rings. The more important difference can be observed at the locality Klimkovice - Sanatoria where percentage of PAHs with three rings is higher approximately by $13 \%$ in comparison with values typical for other areas.

\section{IDENTIFICATION OF SOURCES OF PAHS BY MEANS OF CLUSTER ANALYSIS}

The cluster analysis (software STATGRAPHIC 5) was performed for identification of sources of PAHS. All 16 analytes of PAHs were utilized for cluster analysis. From
Fig. 3 it is apparent that localities were divided into 4 clusters. The division of localities into clusters does not correspond to the proposed division into four groups (mountain area, urban area with industrial activity, urban area without industrial activity and area with prevalence of domestic heating). The cluster I contains localities with the median value of $280 \mathrm{ng} / \mathrm{m}^{3}$. The cluster II consists of 8 localities with the minimum value of PAHs $310 \mathrm{ng} / \mathrm{m}^{3}$, maximum value $507 \mathrm{ng} / \mathrm{m}^{3}$ and the median value $424 \mathrm{ng} / \mathrm{m}^{3}$. The cluster III includes 9 localities with the minimum value of $\Sigma$ PAHs $41 \mathrm{ng} / \mathrm{m}^{3}$, maximum value $170 \mathrm{ng} / \mathrm{m}^{3}$ and the median value $96 \mathrm{ng} / \mathrm{m}^{3}$. The localities with the lowest measured concentrations of PAHs belong to this cluster, The cluster IV contains 9 localities with the highest measured values of $\Sigma$ PAHs, the median value reaches 813 $\mathrm{ng} / \mathrm{m}^{3}$. The comparison of percentage values of individual analytes of PAHs in these cluster shows that their representation in cluster is very similar and this criterion cannot be used for distinguishing of clusters.

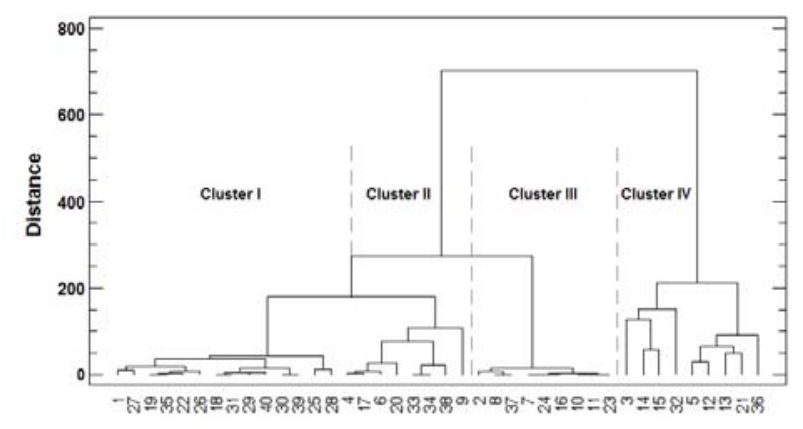

Figure 3. Dendrogram according to the localities for 16 analytes of PAHs

\section{CONCLUSIONS}

It was determined that the value of geochemical background for $\Sigma 16$ PAHs was exceeded at 13 localities from 40 that were studied. PAHs with 3 and 4 benzene rings are most abundant in atmosphere of the territory of Moravian-Silesian Region. The percentage of their representation in the sum of PAHs ranges between 76.7 and $95.0 \%$. Cluster analysis did not confirm the division of localities into the categories (mountain area, town with industrial activity, town without significant industrial activity, domestic heating). The division of localities into cluster was determined by measured concentrations of PAHs. The results show that during the winter season, the environment in towns with industrial activities is comparable with areas with prevailing domestic heating.

\section{ACKNOWLEDGEMENTS}

This paper was supported by research projects of the Ministry of Education, Youth and Sport of the Czech Republic: the Centre ENET CZ.1.05/2.1.00/03.0069 and the Technology Agency of the Czech Republic TA02020004 The research of chemical and physical character of particles in emissions. 


\section{REFERENCES}

[1] Kim, K.H., Jahan, S.A., Kabir, E. \& Brown, R.J.C. A review of air bornepolycyclicaromatichydro carbons (PAHs) and their human health effects. Environment International, 60, pp. 71-80, 2013.

[2] Kakimoto, K., Nagayoshi, H., Konishi, Y., Kajimura, K. Ohura, T., Hayakawa, K. \&Toriba, A. Atmospheric chlorinated polycy clicaromatichydro carbons in East Asia. Chemosphere, 111, pp. 4046, 2014.

[3] Fang, G.C., Chang, Ch.N., Wu Y.S., Fu, P.P., Yang, I.L. \&Chen, M$\mathrm{H}$. Characterization, identification of ambient air and roaddust polycy clicaromatichydro carbons in central Taiwan, Taichung.Science of the Total Environment, 327, pp. 135-146, 2004.

[4] Jung, K.H., Patel, M.M., Moors, K., Kinney, P.L., Chillrud, S.N., Whyatt, R., Hoepner, L., Garfinkel, R., Yac, B., Ross, J., Camann, D., Perera, F.P. \&Miller, R.L. Effects of heating season on residential indoor and outdoor polycy clicaromatichydro carbons, black carbon, and particulate matter in anurbanbirthcohort.AtmosphericEnvironment, 44(36), pp. 4545-4552, 2010.

[5] Saxena, M., Singh, D.P., Saud, T., Gadi, R., Singh, S., Sharma, S.K. \& Mandal, T.K. Study on particulate polycy clicaromatichydro carbon sover Bay of Bengal in winter season. AtmosphericResearch, 145-146, pp. 205-213, 2014.

[6] He, J., Fan, S., Meng, Q., Sun, Y., Zhang J. \&Fan Z. Polycy clicaromatichydro carbons (PAHs) associated with fine particulate matters in Nanjing, China: Distributions, sources and meteoro logical influences. Atmospheric Environment, 89, pp. 207-215, 2014.

[7] Kucharova, J.,Raclavska, H.,Corsaro, A.\&Raclavsky, K. Characterization of Organic Matter Released during Analytical Pyrolysis of $\mathrm{PM}_{10}$ Samples Obtained from Biomass and Oil Combustion. Advanced Materials Research. 926-930, pp. 7-12, 2014.

[8] Ravindra, K.,Sokhi, R.\& Van Grieken, R. Atmospher icpolycy clicaromatichydro carbons: Source attribution, emission factors and regulation. Atmospheric Environment, 42, pp. 2895-2921, 2008.

[9] Tobiszewski, M. \&Namieśnik, J. PAH diagnosticratios for the identification of pollution emission sources. EnvironmentalPollution, 162, pp. 110-119, 2012
[10] Shen, G., Wei, S., Zhang, Y., Wang, B., Wang, R., Shen, H. Li, W., Li, Y., Huang, Y., Chen, H. \&Tao, S. Emission and size distribution of particle-bound polycyclicaromatichydro carbons from residential wood combustion in rural China. Biomass and Bioenergy, 55, pp. 141-147, 2013.

[11] Yang, H.-H., Lai, S.-O., Hsieh, L.-T., Hsueh, H.-J. \&Chi, T. Profilesof PAH emissionfromsteel and iron industries. Chemosphere, 48(10), pp. 1061-1074, 2002.

[12] Ancelet, T., Davy, P.K., Trompetter, W.J., Markwitz A. \&Weatherburn, D.C.. Carbon aceousaerosols in anurbantunnel. AtmosphericEnvironment, 45, pp.4463-4469, 2011.

[13] Phuleria, H.C., Geller, M. D., Fine, P.M. \&Sioutas, C. SizeResolved Emissions of Organic Tracers from Light- and Heavy-Duty Vehicles Measured in a California Roadway Tunnel. Environmental Science and Technology, 40(13), pp. 4109-4118, 2006.

[14] Teixeira, E.C., Agudelo-Castañeda, D.M., Guimarães Fachel, J. M., Leal, K.A., OliveiraGarcia, K. \&Wiegand, F. Source identification and season alvariation of polycyclicaromatichydrocarbons associated with atmosphericfine and coarseparticles in the Metropolitan Area of Porto Alegre, RS, Brazil. Atmospheric Research, 118(15), pp. 390403, 2012.

[15] Omar, N.Y.M.J, Abas, M.R. B., Ketuly, K. A. \& Tahir, N.M. Concentrations of PAHs in atmospheric particles $\left(\mathrm{PM}_{-10}\right)$ and road sides oil particles collected in Kuala Lumpur, Malaysia. Atmospheric Environment, 36(2), pp. 247-254, 2002.

[16] Pisupati, S.V. Wasco, R.S. \& Scaroni, A.W. An investigation on polycyclic aromatic hydrocarbon emissions from pulverized coal combustion systems. Journal of Hazardous Materials, 74, pp. 91-107, 2000.

[17] Li, CH.-T., Mi, H.-H., Lee, W.-J. You, W.-CH. \& Wang, Y.-F. PAH emission from the industrial boilers. Journal of Hazardous Materials. 69(1), pp. 1-11, 1999.

[18] Matschullat, J., Ottenstein R. \& Reimann, C. Geochemical background - can we calculate it?. Environmental Geology, 39(9), pp. 990-1000, 2000.

[19] Nakić, Z., Posavec, K. \&Bačani, A. A Visual Basic Spread sheet Macrofor Geochemical Background Analysis. GroundWater. 45(5), pp. 642-647, 2007. 